

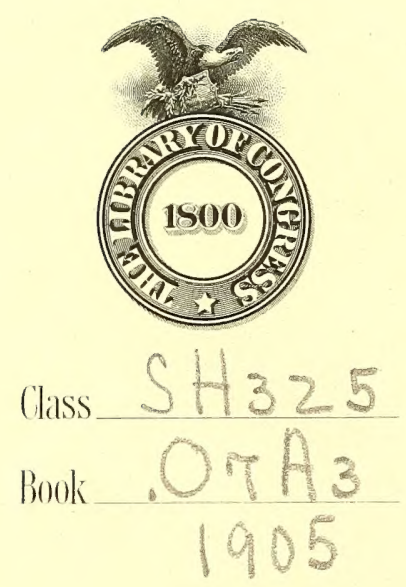







\section{A W S}

PERTAING TO

\section{THE FISHING INDUSTRY}

OF THE

\section{STATE OF OREGON}

\section{5}

Senate Concurrent Resolution No. 29

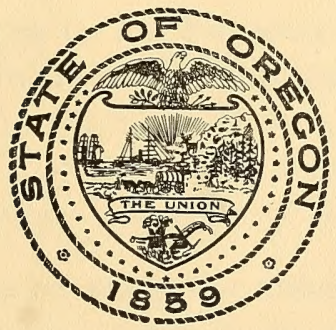

SALEM, OREGON :

J. R. WHITNEY, STATE PRINTER, 1905 . 


$$
\begin{aligned}
& 4+325 \\
& 190^{5}
\end{aligned}
$$

$$
\begin{gathered}
12.0 C T 1905 \\
\text { D. Of D? }
\end{gathered}
$$




\section{OREGON IAWS}

PERTAINING TO

\section{THE FISHING INDUSTRY}

As Contained in Bellinger and Cotton's AnNotated Codes AND STATUTES OF OREGON, TOGETHER WITH ALL LAWS AND AMENDMENTS THERETO, INCLUDING THE LAWS ENACTED AT THE TWENTY-THIRD

Legislative Assembly, Taking Effect May, 18, 1905.

\section{OF FISHERIES.}

THE PROTECTION OF SALMON.

\section{4059. Salmon Defined.}

Wherever the word "salmon" is used in this act the same shall be deemed and held to include chinook, steelheads, and all other anadromous species of salmon and trout. [L. 1901, p. $329, \S 1$.

\section{¿4060. Salmon Fishing by Act Following.}

It shall be unlawful to take or fish for salmon in any rivers or their tributaries in the State of Oregon, or any waters over which the State of Oregon has concurrent jurisdiction, except as hereinafter provided. [L. 1901, p. 329, § 2.]

8 4061. Closed Season for Salmon on Columbia West of Des Chutes.

It shall hereafter be unlawful to take or fish for salmon fish or sturgeon in the Columbia River or any of the waters or sloughs thereof west of its confluence with the Des Chutes River or within three miles outside of the mouth of said Co- 
lumbia River, by any means whatever, between March 15 , noon, and April 15, noon, or between August 25, noon, and September 10, noon, of any year. [L. 1905, p. 238, § 1.]

\% 4062. Salmon Fishing, Except With Rook, on Columbia East of Des Chutes Prohibited.

It shall be unlawful to take or fish for salmon at any time by any means whatever, except with hook and line, commonly called angling, or to take or fish for salmon in any manner whatever during the spawning season on any spawning bed or shallow, where salmon are wont to lie and deposit their spawn, in the Columbia River or any of its tributaries east of its confluence with the Des Chutes River. [L. 1901, p. 329, \& 4.]

\section{\& 4063. Willamette and Tributaries, Closed Season On.}

It shall be unlawful to take or fish for salmon in the Willamette River and its tributaries, north of the falls at Oregon City, by any means whatever, except with hook and line, commonly called angling, from March 15, noon, to April 15, noon, and from June 15, noon, to November 1, noon, in any year ; or to take or fish for salmon by any means whatever after. the passage of this act, except with hook and line, commonly called angling, in the Willamette River or any of its tributaries south of the lower part of the falls at Oregon City. [L. 1905, p. $238, \& 2$.

\section{\% 4064. Rogue River and Tributaries, Closed Season On.}

It shall hereafter be unlawful to take or fish for salmon in Rogue River and its tributaries, or in Big Butte Creek and its tributaries, above their confluence, except with rod and line, commonly called angling; or to take or fish for salmon in Rogue River and its tributaries between the mouth of said Big Butte Creek and the mouth of the Illinois River, and in said Illinois River and its tributaries, by any means whatever, except with rod and line, commonly called angling, from March 15 to April 15, and from August 1 to December 31 in any year; or to take or fish for salmon in Rogue River and its tributaries by any means whatever, west of its conflu- 
ence with the Illinois River, from March 1 to April 1, and from August 15 to September 1 in any year, or within three miles outside of the mouth of said Rogue River from May 1 to August 1 in any year. [L. 1905, p. 239, \& 3.]

\section{:4065. Tillamook Bay and Tributaries, Closed Season On.}

It shall be unlawful to take or fish for salmon in the tributaries of Tillamook Bay, above tide water, at any time, by any means whatever, except with hook and line, commonly called angling, or in any of the waters of Tillamook Bay or its tributaries, below the points hereinafter named, between March 20 and July 15 of each year, or between November 20 and December 10 of each year; or in any of the following named streams, being tributaries of Tillamook Bay, except with hook and line, commonly called angling, from March 20 to December 10 , above the points hereinafter named, namely:

Miami River-At the intersection of said stream by the south line of section 11, in township 1 north of range 10 west of Willamette meridian.

Kilchis River-At the intersection of said stream by the east line of section 12 , in township 1 south of range 10 west of the Willamette meridian.

Wilson River-At the intersection of said stream by the quarter section line running north and south through section 20 , in township 1 south of range 9 west of Willamette meridian.

Hoquarton Slough-At the intersection of said slough by the west line of section 24, in township 1 south of range 10 west of Willamette meridian.

Trask River-At the intersection of said river by the quarter section line running east and west through section 26 , in township 1 south of range 10 west of Willamette meridian.

Tillamook River-At the intersection of said stream by the west line of section 7 , in township 2 south of range 9 west of Willamette meridian. [L. 1905, p. 239, § 4.] 
8.4066. Alsea River, Bay, and Tributaries, Closed Season On.

It shall be unlawful to take or fish for salmon in the tributaries of Alsea Bay, above tide water, at any time by any means whatever, except by hook and line, commonly called angling; or to take or fish for salmon in any of its bays or tributaries below tide water from 6 P. M. Saturday to 6 P. M. the Sunday following in any week of any year, or from the first day of March until the twentieth day of August and from the twentieth day of November until the twentieth day of December of each year. [L. 1901, p. 331, \& S.]

The foregoing act was filed in the oflice vision is in conflict with the last preceding of the Secretary of State on February 28 , section, and is superseded by it, the act to 1901. An act approved February 25, 1901, which such section belongs being the later (L. p. 134, amending an act passed in 1889, act. The act in question purports to amend (L. p. 63,) provides that it shall be unlaw- section 1 of the act of 1899 , of which latter ful for any person or persons to take or aet therewere but two sections (the section fish for salmon in the waters of the Alsea amended aud a penal provision for its enRiver, bay, and tributaries from the first forcement.) The two succeeding sections day of July until the twentieth day of Au- are sections 2 and 3 of the act of February gust or from the twentieth day of Novem- 25, 1901.

ber until the twentieth day of December of each year. It will be seen that this pro-

84067. Fish Wheels, Traps, etc., in Alsea Bay, River, and Tributaries Unlawful.

It shall be unlawful for any person, association, or corporation to build, construct, or operate any fish trap or fish wheel, or any mechanical contrivance for the purpose of catching salmon, in any of the waters of the Alsea Bay, river, or its tributaries. [L. 1901, p. 134, § 2.]

\section{Yaquina Bay-Mill Creeß - Angling.}

That hereafter it shall be unlawful to fish at any season of the year, at any point above the mouth of Mill Creek, on Yaquina Bay, or its tributaries, with any appliance whatever, except with fishlook and line, or what is commonly called angling. [L. 150\%, p. $143, \S 1$.

\section{Alsea Bay - Gravel Bar-Angling.}

That hereafter it shall be unlawful to fish at any season of the year, at any point above what is known as Gravel Bar, one half mile below Tidewater post office, on the Alsea Bay, or its tributaries, except with fishhook and line, or what is commonly called angling. [L. 1903 , p. 143, \& 2.] 


\section{Penalty for Violating.}

Any person or persons violating any of the provisions of this act shall be guilty of a misdemeanor, and upon conviction thereof shall be fined in the sum of not less than $\$ 25$ nor more than $\$ 100$. [L. 1903, p. $143, \S 5$.]

\section{Duties of Officers.}

It shall be the duty of every sheriff, constable, or peace officer to inform upon and prosecute any person or persons found violating any of the provisions of this act. [L. 1903, p. 143, § 6.]

\section{Penalty for Violation of Foregoing Provision.}

Any person, association, or corporation violating any of the provisions of this act shall be guilty of a misdemeanor, and upon conviction thereof shall be fined in a sum not less than $\$ 50$ nor more than $\$ 500$. [L. 1901, p. 134, § 3.]

\section{Umpqua River and Tributaries, Closed Season On.}

It shall be unlawful to take or fish for salmon in the Umpqua River, or any of the bays or tributaries thereof, below the points hereinafter named, from March 20 to May 15, and from November 20 to December 10 of any year; or to take or fish for salmon by any means whatever, except with hook and line, commonly called angling, and for propagating purposes, above the points specified on each stream, namely: North Fork, above the railroad bridge crossing said stream at the town of Winchester; South Fork, above the south boundary line of the town of Roseburg. [L. 1905, p. 240, \& 5.]

\section{\$4070. Coos Bay, Coquille River, and Tributaries, Closed Season On.}

It shall be unlawful to take or fish for salmon in Coos Bay or Coquille River, or their tributaries, or Lower Ten-Mile Creek, at any time or by any means whatever, between $6 \mathrm{~A}$. I. on the twentieth day of March and 6 P. M. on the fifteenth day of July, or between 6 A. M. on the twentieth day of November and 6 P. M. on the tenth day of December of any year. It shall be unlawful to take or fish for salmon at any time, except with hook and line, commonly called angling, in the South Fork of 
the Coquille River above the junction of the same at what is known as "Hoffman's Bridge," or in the north or east forks of said river above the junction of said north and east forks. It shall be unlawful to take or fish for salmon at any time, except with hook and line, commonly called angling, in the north or south forks of Coos River, above the junction of the two streams, excepting during the season commencing at 6 P. M. on the tenth day of December and ending at 6 A. M. on the twentieth day of March, during which time salmon may be caught, other than with hook and line, as far as the forks of the North Fork, commonly known as "Allegany," and as far as the island opposite the "Mark Cutlip " place in the South Fork. [L. 1905, p. 241, §6.]

\section{¿4071. Coast Streams, Closed Eeason On.}

It shall be unlawful to take or fish for salmon in any of the following named streams, or any of their tributaries, above tide water, at any time by any means whatever, except with hook and line, commonly called angling, or any of their bays or tributaries, below tide water, between $6 \mathrm{~A}$. м. on the twentieth day of March and 6 P. M. on the fifteenth day of July, or between $6 \mathrm{~A}$. M. on the twentieth day of November and 6 P. м. on the tenth day of December of any year, namely: Windchuck River, Chetco River, Pistol River, Elk River, Sixes River, Upper Ten-Mile Creek, Alsea Bay and river, Beaver Creek, Siletz River, Salmon River, Nestucea Bay and river, Elk Creek, and Klamath River. It shall be unlawful to take or fish for salmon in the Siuslaw River, or its tributaries, at any time by any means whatever, except with hook and line, commonly called angling, above Mapleton on said river, or to take or fish for salmon in any of its tributaries or bays below Mapleton from 6 A. M. on the twentieth day of March to 6 P. м. on the fifteenth day of July, or from 6 A. M. on the twentieth day of November to 6 P. M. on the tenth day of December of any year, except with hook and line commonly called angling. It shall be unlawful to take or fish for salmon in the Yaquina Bay, or its tributaries, at any time by any means whatever, 
cxcept with hook and line, commonly called angling, at any point above the mouth of Mill Creek, or to take or fish for salmon in any of its bays or tributaries below the mouth of Mill Creek from 6 A. M. on the twentieth day of March to 6 P. M. on the fifteenth day of July, or from 6 A. M. on the twentieth day of November to the tenth day of December in any year. It shall be unlawful to take or fish for salmon in the Nehalem River, or its tributaries, at any time by any means whatever, except with hook and line, commonly called angling, above a point on said river three miles below its confluence with Foley Creek, or to take or fish for salmon below said point, on said river, from $6 \mathrm{~A}$. M. on the twentieth day of March to $6 \mathrm{P}$. M. on the fifteenth day of July, or from 6 A. x. on the twentieth Cay of November to 6 P. . on the tenth day of December of any year, except with hook and line, commonly called angling. [L. 1905, p. $241, \S 7$.

\section{\& 4072. Traps, Weirs, Fishing Dams, and Fish Wheels.}

It shall be unlawful for any person or persons to construct, maintain, or operate any trap, weir, fishing dam, or fish wheel in any of the following named streams, or to operate any set net or other fixed appliance which shall extend more than one third across any of the waters thereof: Willamette River and its tributaries, Rogue River and its tributaries, Umpqua River and its tributaries, Tillamook Bay and its tributaries, Alsea Bay and its tributaries, Windchuck River, Chetco River, Pistol River, Elk River, Sixes River, Coquille River, Coos Bay, Lower Ten-Mile Creek, Upper Ten-Mile Creek, Siuslaw River, Beaver Creek, Yaquina Bay, Siletz River, Salmon River, Nestucca Bay, Nehalem River, Elk Creek, Necanicum River, Klamath River and tributaries; provided, that the provisions of this section shall not be construed to apply to that portion of the Necanicum Creek, or river, below the lowermost bridge which is now constructed on said creek or river, or their tributaries. [L. 1901, p. 332, § 12.]

An act passed in 1899 (L. p. 72,) provided a close season for the waters of Sixes, Elk, their tributaries and bays, and for any other stream in Curry County, and for Rogue River, the Illinois River, and their tributaries. The act is superseded by the fish law of 1901 , except as to the next succeeding section (section 2 of the act referred to), which gives to riparian owners the exclusive right of fishing with seines and nets on each "of said rivers," the rivers above mentioned. 


\section{Riparian Owners, Exclusive Rights of.}

The owner or owners of tide lands, and riparian owners above tide water, on each side of said rivers, as appurtenances thereto, shall have the exclusive right and privilege of fishing for salmon fish with seines and nets and hauling and landing seines and nets on said lands, and no person or persons shall anchor said nets, or put or place any obstruction or obstructions whatever in the water fronting said tide lands in any place or places where said tide lands are used for hauling or landing seines. [L. 1899, p. $72,82$.

Idem - Necanicum River- Exception.

It shall be unlawful hereafter for any person or persons to construct, operate, or maintain or place, or permit to be placed, constructed, operated, or maintained, in any of the waters of the Necanicum River, or any tributary thereof, any fish trap, pound net, or any fixed device howsoever constructed, excepting only a set net, to be constructed as hereinafter provided, for the purpose of, or which is capable of, taking or catching or impeding the run of fish of any kind up said stream. [L. 1903 , p. $159, \S 1$.

\section{Set INets - Construction, Operation, etc.}

It shall be unlawful for any person or persons to construct, operate, maintain, or place, or suffer or permit to be operated, maintained, or placed, in the waters of the Necanicum Creek, or any of its tributaries, any set net, excepting when the same shall be constructed, operated, maintained, and placed in the manner following, that is to say:

1. The meshes in each set net must not be less than seven

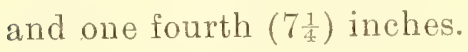

2. A clear passageway of at least one third, and, in any event, sixteen feet in the center of the main channel shall be at all times maintained unobstructed by any such net or any contrivance placed thereon, or any wing placed thereon or leading thereto.

3. There shall be at least a distance of five hundred feet between each net. [L. 1903, p. 159, \& 2.] 


\section{Seine or Drag Net - Mesh.}

It shall be unlawful hereafter for any person or persons to operate, or cause to be operated or placed, in the waters of the Necanicum Creek, or any tributary thereof, any seine or drag net, or like contrivance, any mesh of which is less than seven and one quarter ( $\left.7 \frac{1}{4}\right)$ inches. [L. 1903, p. 160, \& 3.]

\section{Idem - Size of Mesh, How Determined.}

For the purpose of determining the size of any mesh in any seine or drag net or set net, or like contrivance, mentioned in this act, the mesh shall be measured diagonally from opposite corner to opposite corner, stretched taut. [L. 1903, p. 160, § 4.]

\section{Penalty for Violation.}

Any person violating any of the provisions of this act shall be deemed guilty of a misdemeanor, and upon conviction shall be punished by fine not less than $\$ 50$ nor more than $\$ 250$, or by imprisonment in the county jail not exceeding one hundred and twenty-five days, or both fine and imprisonment. [L. 1903, p. $160, \S 5$.

\section{Jurisdiction - Justice Courts.}

Justices of the peace shall have concurrent jurisdiction with the circuit court of any violation of the provisions of this act. [L. 1903, p. $160, \S 6$.

\section{Young Salmon in Tide Waters Protected.}

It shall be unlawful to take or fish for the young of salmon, under twelve inches in length, in any waters of the State of Oregon, or in the waters of any of the rivers or bays over which the State of Oregon has concurrent jurisdiction, at any time or in any manner whatever; or to take, fish for, stone, club, shoot, with any description of firearm, spear, foul hook, or molest, wound, kill, or injure, in any manner at any time whatever, or to expose for sale or have in possession, except for the purpose of propagation, any gravid or spawning salmon. [L. 1903, p. $233, \S 6$. 
\% 4075. Gaffs, Spears, and Foul Hooks, Prohibited- Fogue River Waters Excepted.

It shall be unlawful at any time whatever to take, fish for, or pursue salmon in any of the rivers and their tributaries in the State of Oregon, or in any waters over which the State of Oregon has concurrent jurisdiction, with spear, gaff, or foul hook, or other device, whether used with rod and line or otherwise, for the purpose of foul-hooking salmon; provided, that nothing in this act shall be construed to affect operations and rights of the North American Indians who have not severed their tribal relations. [L. 1903, p. 233, \& 8.]

\section{\%4076. Penalties for Violating Fish Act - Burden of Proof - Disposi- tion of Contraband Fish.}

Any person or persons, firm or corporation, found fishing or taking, catching, or transporting salmon fish or sturgeon in or upon any of the waters of this State, or in or upon any of the waters over which this State has concurrent jurisdiction, or found making use of any boat or boats, vessel or vessels, or any fish trap, weir, pound net, gill net, set net, fish wheel, seine, or any other device intended for or which is capable of being used to eatch or transport salmon fish or sturgeon, in or upon any of the waters of this State, or in or upon any of the waters over which this State has concurrent jurisdiction; or who shall have in or upon any of the waters of this State, or in or upon any of the waters over which this State has concurrent jurisdiction, or who shall leave or cause to be left in a condition to take or catch salmon fish or sturgeon, in or upon any of the waters of this State, or in or upon any of the waters over which this State has concurrent jurisdiction, any fish trap, weir, pound net, gill net, set net, fish wheel, seine, or any other device intended for or which is capable of being used to catch salmon fish or sturgeon, during any existing closed season or any closed season that may hereafter be enacted; or who may purchase salmon fish or sturgeon, or have in its or their possession salmon fish or sturgeon unlawfully caught during any existing closed season, or any closed season that may hereafter be enacted, shall be deemed guilty of a misdemeanor, and upon conviction 
thereof shall be fined in a sum not less than $\$ 50$ nor more than $\$ 500$, and costs, for each and every offense, and in addition thereto shall forfeit the boat or boats, vessel or vessels, fish trap or fish traps, weir or weirs, pound net or pound nets, gill net or gill nets, set net or set nets, fish wheel or fish wheels, seine or seines, or any other device or devices so unlawfully used, and the salmon fish or sturgeon found in his or their or its possession. All salmon fish or sturgeon so unlawfully caught or taken and all property forfeited under the provisions of this section shall be immediately taken possession of by the fish warden, deputy warden, or water bailiff, and shall be confiscated by said warden, deputy warden, or water bailiff and immediately thereafter turned over to the master fish warden who may dispose thereof at his discretion. The money arising from the sale of salmon fish or sturgeon and all property forfeited under the provisions of this section shall be deposited with the State Treasurer to be placed in the "Hatchery Fund" for the district in which such seizure and confiscation was made. In all prosecutions under this section the possession by any person of salmon fish or sturgeon during any close season, or any close season that may hereafter be enacted for the protection of salmon fish or sturgeon, shall be construed as prima facie evidence that the same were unlawfully caught during said clesed season, and it shall be no defense that the fish were caught or taken outside or within the State.

[L. 1905, p. $426, \S 1$.]

\section{\% 4077. Placing Deleterious Matter or Explosives in Waters of State Unlawful.}

It shall be unlawful for any person or persons to throw or cast or pass, or cause or permit to be thrown or cast or passed, in any waters of the State in which salmon fish of any kind or other food fishes are wont to be, any lime, drug, powder, medicated bait, gas, or cocculus indicus, or any other substance deleterious to fish, or to explode or cause to be exploded in any waters of this State any powder, hercules powder, giant powder, dynamite, nitroglycerine, or any explosive substance whatever, for the purpose of catching, killing, or destroying any salmon or any food fish.

[L. 1901, p. 336, § 22.] 


\section{BOARD OF FISH COMMISSIONERS.}

3078. Authorized to Appoint Fish Warden, Deputy and Special Deputy - Duties and Compensation of Wardens.

The Governor, Secretary of State, and State Treasurer are hereby created a Board of Fish Commissioners. It shall be the duty of such fish commissioners to appoint one Master Fish Warden, and also one deputy, who shall be known as Deputy Fish Warden, who shall have the same power and authority for enforcement of the law as the Master Firsh Warden. They shall hold their offices at the pleasure of the Board of Fish Commissioners, who may summarily remove them whenever in their judgment they shall deem such a change for any cause advisable. Before entering upon the duties of his office, the said Master Fish Warden shall file with the Secretary of State a bond, to be approved by the board, in the sum of $\$ 25,000$, with two or more sureties, conditioned for the faithful performance of his duties as prescribed in this act. His compensation shall be $\$ 2,500$ per year, to be paid quarterly from the general fund, and he shall be allowed for hire of patrol boats and his actual traveling expenses, office, and other necessary expenses in the performance of his duties, the sum of $\$ 1,700$ per year, to be paid from the said fund. The Deputy Fish Warden shall, before entering upon his duties, execute a bond with one or more sureties, to be approved by the board, in the sum of $\$ 1,000$ to the State of Oregon, condritioned for. the faithful performance of his duties. The Deputy Fish Warden shall devote his entire time and attention to the fish industry of the State, under the direction of the board and-supervision of the Master Fish Warden, and shall receive a salary of $\$ 1,000$ per year, payable quarterly from said fund, and he shall be allowed for his actual traveling expenses while in the performance of his duties, the sum of $\$ 500$ per annum. The Board of Fish Commissioners is hereby authorized to appoint a special deputy for any stream in the State, who shall be known as "Water Bailiff," and who shall reside in the vicinity of said stream for which he is appointed. Such water bailiff shall have the power to enforce the fish laws in any part of the State, under the direc- 
tion of the master or deputy wardens. The special deputy shall receive the sum of $\$ 3.00$ per day while in the actual performance of his duties, and shall receive for his actual traveling expenses, upon vouchers for the same, not to exceed $\$ 2.00$ per day, while in the performance of his duties, the same to be paid out of the "hatchery fund." [L. 1901, p. 334, § 16.]

FISH HATCHERIES.

\section{Commissioners to Locate and Wardens to Construct Hatch- eries.}

It shall be the duty of such fish commissioners to select and locate, or direct the selection and location of, suitable sites for the construction of fish hatcheries, and direct the fish wardens to construct thereat such hatcheries as in the judgment of the board will be to the best interests of the fishing industry. Said commissioners shall have the right to pay out all moneys in the hatchery fund provided by law for the construction and operation of fish hatcheries; also to audit all bills of the fish wardens before the same are paid, and to generally exercise a supervisory control over the fish wardens and all fish hatcheries of the State. [L. 1901, p. 335, \& 17.]

\section{\% 4080. "Hatchery Fund," Money and Fines Collected to Constitute- Districts.}

For the purposes of this act the State of Oregon is hereby divided into fishing districts as follows: District No. 1 shall include that portion of the Columbia River and its tributaries over which the State of Oregon has jurisdiction. District No. 2 shall include all the coast streams and their tributaries in the State of Oregon south of the Columbia River. The fish warden shall collect and receive all license fees, fines or parts of fines, or proceeds arising from the sale of confiscated fish or fishing appliances, under the provisions of this act, and shall pay the same to the State Treasurer within thirty days after collection or receipt thereof, to be placed in the hatchery fund, said fund to be used for hatchery purposes under direction of the Board of Fish Commissioners. All sums of money collected in any district shall be by the State Treasurer credited to the "hatch- 
ery fund" of such district, and in paying over moneys collected. the fish wardens shall designate the district in which all moneys were collected; he shall take a receipt, in duplicate, from the State Treasurer, one he shall file in his own office and the other in the office of the Secretary of State. The money collected in any district shall not be expended, except in the district in which it was collected. All moneys now in the "hatchery fund," after all outstanding accounts against said fund have been paid, shall be apportioned and transferred as follows: Two thirds to the hatchery fund of District No. 1; one third to the hatchery fund of District No. 2; and the Secretary of State shail issue his warrants on the State Treasurer, making such transfer from the "hatchery fund." Upon the payment of any judgment that may have been obtained against any person or persons for the violation of any of the provisions of this act, the same shall be satisfied by the district attorney, upon the presentation of the receipt of the Master Fish Warden. [L. 1903, p. 234, § 10.]

\section{\%4081. Private Salmon Hatchery, Payment to Out of License Minoney.}

When there shall be in operation on any river of this State, for the purpose of stocking said river or its tributaries with salmon, owned by any person or persons or corporation, the Board of Fish Commissioners, upon proper evidence that said salmon hatchery shall have been operated in any year in such a manner as to produce a benefit to such stream equal to that derived from the same amount of money expended at hatcheries maintained and operated by the Board of Fish Commissioners, the said Board of Fish Commissioners shall pay over to such person or persons or corporation not to exceed sixty per cent of the moneys received by such board for licenses from such persons engaged in fishing or packing fish on such river or its tributaries; the same to be used by such person or persons, firm, or corporation in propagating salmon in such river or its tributaries. [L. 1901, p. 335, § 19.] 
8 4082. Construction and Operation of Hatcheries in Adjoining States.

The State Board of Fish Commissioners is hereby authorized to construct, maintain, or operate salmon hatcheries in an adjoining State, and to expend a portion of the money in the "hatchery fund" for that purpose; provided, that no hatchery shall be constructed or operated on any stream in an adjoining State that is not a tributary of the Columbia River, or whose waters do not flow into said Columbia River. [L. 1901, p. $336, \S 20$.]

\section{4083. Racks or Other Obstructions for Hatchery Purposes.}

The Fish Commissioner and the Fish Commission of the United States Government, or any individual operating hatcheries in this State, are hereby authorized to erect racks, traps, or other obstructions across any of the streams in this State for the purpose of obtaining salmon for propagating purposes, and it shall be unlawful for any person or persons to injure or destroy and such racks, traps, or obstructions by any means whatever, or take, kill, destroy, or molest any salmon within two miles below any such rack, trap, or obstruction across any stream in this State. [L. 1901, p. 336, § 21.]

Hatcheries on Columbia River and Tributaries - Establishment and Maintenance.

That there be and hereby is appropriated from any money in the State treasury, not otherwise appropriated, the sum of $\$ 15,000$, or so much thereof as may be necessary, for the purpose of establishing, erecting, constructing, and equipping suitable hatcheries for the propagation of salmon fish on the Columbia River and its tributaries in the State of Oregon, one of which hatcheries shall be constructed and maintained on the Wallowa River at some suitable place designated by the Board of Fish Commissioners, and there is also hereby appropriated out of any money in the State treasury, not otherwise appropriated, the sum of $\$ 10,000$ for the operation and maintenance of salmon fish hatcheries on the Coast streams of the State of Oregon, south of the Columbia River. [L. 1905, p. $99, \S 1$. 
Ixpense Claims - To be Approved and Audited.

No part of said sum hereby appropriated shall be used or expended for any purpose whatever, otherwise than as specified in section 1 of this act, at such places as shall be selected by the Board of Fish Commissioners; all vouchers covering expenses incurred in carrying out the provisions of this act, shall be approved by the Board of Fish Commissioners, presented to the Secretary of State for payment, and by him audited as other claims against the State. [L. 1905, p. 99, \&2.]

\section{POSSESSION OF FISH DURING CLOSE SEASON PROHIBITED.}

3.4084. Possession of Fish Caught During Closed Season UnlawfulPresumption From Possession.

It shall be unlawful for any person or persons to receive, or have in his or their possession, or sell or offer for sale or transportation, or transport, during the closed season named in this act, any chinook, steelhead, blueback, silverside, or other species of salmon, caught or taken during any of the close seasons named in this act; and in all prosecutions under this section the possession by any person during the close season named in this act of any chinook, steelhead, blueback, silverside, or other species of salmon, shall be construed as prima facie evidence that the same were unlawfully caught during the close season. [L. 1901, p. 336, \& 23.]

Under the former law it was held that it the State, becoming a part of its general was not a violation of the law to have in property, as to those caught within its limone's possession during the closed season its: State v. Schuman, 36 Or. 16, 58. Pac. salmon caught out of the State or eaught in the State during open season state $\mathrm{v}$. Mc Guire, 24 Or. 366, 33 Pac. 666, $2 \mathrm{i}$ L. R. A. 478.

Under a law prohibiting the possession of trout in closed season however, this case is distinguished and it is held that the law was as much in force against trout lawfully caught in another State and shipped into

661,47 L. R. A. 153,78 Am. St. Rep. 754 .

It is also held that such a law is not invalid as being a regulation of interstate commerce: In re Deininger, 108 Fed. 623.

The wording of this section, however, seems to allow the possession of trout caught in another state or in an open season.

\section{OBSTRUCTION OF STREAMS PROHIBITED.}

\section{\%4085. Obstruction in Fish Stream Prohibited - Taking Fish Within} Six Hundred Feet of Fish Way Unlawful.

It shall be unlawful for any person to construct any milldam or artificial obstruetion across any stream in this State frequented by salmon or trout, or to maintain any such milldam 
or obstruction heretofore erected without providing a passageway for such fish over such obstruction, such passageway for fish to be constructed as near the main channel as may be practicable. It shall be the duty of the fish warden to examine, from time to time, all milldams and artificial obstructions to all rivers and streams in the State frequented by salmon or other migratory fish, and if in his opinion there is not a free passage for fish over any milldam or artificial obstruction, to notify the owner or occupant thereof to provide the same within a reasonable time with a durable and efficient fish way, of such form and capacity and in such location as shall be determined by the fish warden. If such fish way is not completed to the satisfaction of said fish warden within the time specified, the owners or occupants of such milldam or artificial obstruction shall be deemed guilty of a misdemeanor, and on conviction shall be punished as in this act hereinafter provided. It shall be incumbent upon the owners and operators of all milldams or artificial obstructions, where the fish warden requires such fish way to be provided, to keep the same in repair and open and free from obstructions to the passage of fish at all times, and any owner or operator of any dam or artificial obstruction who neglects or refuses to keep such fish way in repair and open and free from obstruction to the passage of fish shall be guilty of a misdemeanor, and upon conviction shall be punished as in this act hereinafter provided; and the continuance from day to day of the neglect or refusal after notification in writing by the fish warden, shall constitute a separate offense; and it shall be unlawful for any person to wilfully or knowingly destroy, injure, or abstract from such fish way, or to take or catch any salmon or other migratory fish within six hundred feet of any fish way. [L. 1901, p. 337, § 24.]

\section{Unlawful to Frighten or Drive Salmon.}

It shall be unlawful for any person to place in any stream of this State where salmon run or exist, within the distance from any dam, fish way or object in which the taking of salmon is prohibited by law, any blood or offal of salmon or fish, or any 
other substance or matter or contrivance that will frighten or drive salmon or with intent to drive or frighten from or out of that part of the waters of any stream in which it is unlawful to fish for or take the same. [L. 1905, p. 94, \& 1.]

\section{Penalty for Violating Preceding Section.}

Any person violating the provisions of this act shall be punished by a fine of not less than $\$ 50$ or not more than $\$ 1,000$, or by imprisonment in the county jail not to exceed six months. [L. 1905, p. 94, § 2.]

\section{そ 4086. Sawdust, etc., Placing in Columbia River by Proprietor of Mill Unlawful.}

It shall be unlawful for any proprietor or operator of any sawmill or other lumber manufacturing concern, or of any pulp mill, wood saw, or other wood-sawing or manufacturing concern in this State, or any employé thereof, or any other person, to cast sawdust, planer shavings, or other lumber waste, or suffer or permit such sawdust, shavings, or other lumber waste to be thrown or discharged in any manner into any waters flowing into the Pacific Ocean within this State, or other waters of this State, or the Columbia River, or to deposit the same where high waters will take the same into any such waters or the Columbia River. Any person or persons, firm, or corporation, violating any of the provisions of this section shall be deemed guilty of a misdemeanor, and upon conviction thereof shall be fined in a sum not less than $\$ 50$ nor more than $\$ 500$, and costs for each and every offense. [L. 1905 , p. $428, \S 2$.

The question whether or not easting saw- a law prohibiting such act, the courts are dust into rivers is injurious to fish is a precluded from examining that question: question for the legislature and not for the State v. Shaw, 22 Or. 290,29 Pac. 1028.

courts, and when the legislature has passed

\section{\% 4087. Fish Wheel, Must Not be Concealed - How Placed.}

It shall be unlawful for any person to place or cause to be placed in any of the rivers or waters of this State, or in any river or water over or upon which this State has concurrent jurisdiction, any fish wheel in a condition to take salmon, or in a position less than three feet above the surface of any such 
river or water, or covered or concealed in such manner that the position of the same can not be clearly discerned from the nearest river bank, during any part of the close season specified in this act. [L. 1901, p. 338, \& 26.]

\section{DEALERS TO REPORT TO WARDEN.}

\section{Dealers MIust Report Fish Purchased.}

It shall be the duty of all persons, firms, or corporations who purchase from fishermen or takers or catchers of fish, or who catch their own fish for the purpose of canning, packing, preserving, or selling them for profit or otherwise, or who pack, preserve, retail, or otherwise deal in fish, to report to the fish warden on or before the fifteenth day of November of each year the number of every species of fish, including clams, crabs, crawfish, oysters, etc., stated separately, so purchased or taken by them during the year ending on said fifteenth day of Norember, and if purchased by weight, the number of pounds of each species so purchased or taken; and said report shall be accompanied by affidavit as to the correctness of the same. Any person, firm, or corporation who fails, neglects, or refuses to comply with the provisions of this section shall be deemed guilty of a misdemeanor, and upon conviction thereof shall be fined in a sum not less than $\$ 50$ nor more than $\$ 500$ and costs, for each and every offense. [L. 1905, p. 428, § 3.]

\section{LICENSE FOR FISHING AND BUSINESS REGULATED.}

\section{4089. License, Fishing Without, Otherwise Than by Angling Pro- hibited.}

It shall be unlawful for any person or persons to take or fish for salmon fish or sturgeon in any of the waters of this State, or in any of the waters upon which this State has concurrent jurisdiction, by any means whatever, except with hook and line, commonly called angling, without first having obtained a license therefor, as in this act hereinafter provided. [L. 1901, p. 338, \& 28.] 


\section{\&4090. Traps, Nets, Fish Wheels, etc., Unlawful to Fish With With- out License.}

It shall be unlawful for any person or persons to operate or maintain, or leave in a condition to take fish, in any of the waters of this State at any time hereafter, any fish traps, weir, pound net, set net, gill net, fish wheel, seine, or any device or apparatus or gear used in catching salmon fish or sturgeon, without first having obtained from the fish warden a license therefor as hereinafter provided. [L. 1901, p. 338, § 29.]

\section{\%4091. Packing or Dealing in Salmon or Sturgeon Without Iicense Unlawful.}

It shall be unlawful for any person or persons, firm, or corporation to engage in the business of packing or dealing in salmon fish or sturgeon within the State of Oregon without first having obtained a license therefor from the fish warden as hereinafter provided. All licenses issued under the provisions of this act shall expire on the thirty-first day of December following the issuance of such license. [L. 1901, p. 338, $\$ 30$.

By the amendment to \& 4093, (L. 1905, p. 116), all licenses expire March 31 following the issuance of same.

\section{Citizens or Persons Flaving Declared Intentions, Fishing Re- stricted to-License From Washington State Sufficient Where.}

It shall be unlawful for any person to take or fish for salmon fish or sturgeon in any waters of this State unless such person be a citizen of the United States, or has declared his intention to become such, and has been a bona fide resident of the State of Oregon, or the States of Washington or Idaho, for the period of six months; provided, that a license issued by the State of Washington, such State having concurrent jurisdiction on the Columbia River with this State, shall be deemed valid as togill nets, and as to gill net fishermen for use on the Columbia River, as though issued by the fish warden of this State. [L. 1903, p. 218, \& 1.]

\section{\$4093. License, Procedure to Obtain-Amount of License Fees.}

Any person who is a citizen of the United States, or who has declared his intention to become such, and is a resident 
of the State of Oregon, or the States of Washington or Idaho, desiring to engage in the business of operating a fish trap, wier, pound net, set net, gill net, fish wheel, or seine, or other fishing appliance not prohibited by law, for the purpose of catching fish in any of the waters of this State, or over which the State of Oregon has concurrent jurisdiction, shall make application in writing to the fish warden of said State, specifying with convenient certainty the character of the appliance that the applicant desires to obtain license for, and the location, if for a stationary appliance, and upon payment of a license fee as hereinafter provided, said fish warden shall issue to such applicant a license to operate the character of appliance desired in said application; provided, that such license shall be good only in the district for which the same is issued. The following license fees for fishing appliances shall be paid by those owning or operating the same: For each drag seine, not exceeding 500 feet in length, $\$ 15$; for each additional foot in length the further sum of three cents; for each gill net, $\$ 5.00$; for each set net, $\$ 2.50$; for each pound net, trap, or weir, $\$ 25$; for each scow fish wheel, $\$ 25$; for each stationary fish wheel, $\$ 35$. All licenses issued under the provisions of this section shall expire on the thirty-first day of March following the issuance of such license. [L. 1905, p. 116, § 1.]

\section{4094. Canneries Classified - License Fees to be Paid.}

Any person, firm, or corporation engaged in the business of canning fresh salmon in hermetically sealed tins or cans in this State shall pay license fees as follows: Those of the first class, $\$ 100$; second class, $\$ 150$; third class, $\$ 200$; fourth class, $\$ 250$; fifth class, $\$ 300$; sixth class, $\$ 350$; seventh class, $\$ 400$; eighth class, $\$ 450$; ninth class, $\$ 500$; tenth class, $\$ 550$; eleventh class, $\$ 600$; twelfth class, $\$ 650$; thirteenth class, $\$ 700$; fourteenth class, $\$ 750$; fifteenth class, $\$ 800$; sixteenth class, $\$ 850$; seventeenth class, $\$ 900$; eighteenth class, $\$ 950$; ninteenth class, $\$ 1,000$; twentieth class, $\$ 1,050$; twenty-first class, $\$ 1,100$; twenty-second class, $\$ 1,150$; twenty-third class, 
$\$ 1,200$; twenty-fourth class, $\$ 1,300$; twenty-fifth class, $\$ 1,500$. Canners of the first class are those whose pack of salmon fish for the year next preceding the year that the license is applied for does not exceed 5,000 cases of salmon, fortyeight pounds to the case. Those of the second class are canners whose pack for the year next preceding the year the license is applied for exceeded 5,000 cases, but did not exceed 7,500 cases of salmon, forty-eight pounds to the case. Those of the third class are canners whose pack for the year next preceding the year the license is applied for exceeded 7,500 cases, but did not exceed 10,000 cases, forty-eight pounds to the case. Those of the fourth class are canners whose pack for the year next preceding the year the license is applied for exceeded 10,000 cases, but did not exceed 12,500 cases of salmon, forty-eight pounds to the case. Those of the fifth class are canners whose pack for the year next preceding the year the license is applied for exceeded 12,500 cases, but did not exceed 15,000 cases of salmon, forty-eight pounds to the case. Those of the sixth class are canners whose pack for the year next preceding the year the license is applied for exceeded 15,000 cases, but did not exceed 17,500 cases of salmon, forty-eight pounds to the case. Those of the seventh class are canners whose pack for the year preceding the year the license is applied for exceeded 17,500 cases, but did not exceed 20,000 cases of salmon, forty-eight pounds to the case. Those of the eighth class are canners whose pack for the year next preceding the year the license is applied for exceeded 20,000 cases, but did not exceed 22,500 cases of salmon, forty-eight pounds to the case. Those of the ninth class are canners whose pack for the year next preceding the year the license is applied for cxceeded 22,500 cases, but did not exceed 25,000 cases of salmon, forty-eight pounds to the case. Those of the tenth class are canners whose pack for the year next preceding the year the license is applied for exceeded 25,000 cases, but did not exceed 27,500 cases of salmon, forty-eight pounds to the case. Those of the eleventh class are canners whose pack for' the year next preceding the year the license is applied for ex- 
ceeded 27,500 cases, but did not exceed 30,000 cases of salmon, forty-eight pounds to the case. Those of the twelfth class are canners whose pack for the year next preceding the year the license is applied for exceeded 30,000 cases, but did not exceed 32,500 cases of salmon, forty-eight pounds to the case. Those of the thirteenth class are canners whose pack for the year next preceding the year the license is applied for exceeded 32,500 cases, but did not exceed 35,000 cases of salmon, forty-eight pounds to the case. Those of the fourteenth class are canners whose pack for the year next preceding the year the license is applied for exceeded 35,000 cases, but did not exceed 37,500 cases of salmon, forty-eight pounds to the case. Those of the fifteenth class are canners whose pack for the year next preceding the year the license is applied for exceeded 37,500 cases, but did not exceed 40,000 cases of salmon, fortyeight pounds to the case. Those of the sixteenth class are canners whose pack for the year next preceding the year the license is applied for exceeded 40,000 cases, but did not exceed 42,500 cases of salmon, forty-eight pounds to the case. Those of the seventeenth class are canners whose pack for the year next preceding the year the license is applied for exceeded 42,500 cases, but did not exceed 45,000 cases of salmon, fortyeight pounds to the case. Those of the eighteenth class are canners whose pack for the year next preceding the year the license is applied for exceeded 45,000 cases, but did not exceed 47,500 cases of salmon, forty-eight pounds to the case. Those of the nineteenth class are canners whose pack for the year next preceding the year the license is applied for exceeded 47,500 cases, but did not exceed 50,000 cases of salmon, fortyeight pounds to the case. Those of the twentieth class are canners whose pack for the year next preceding the year the license is applied for exceeded 50,000 cases, but did not exceed 52,500 cases of salmon, forty-eight pounds to the case. Those of the twenty-first class are canners whose pack for the year next preceding the year the license is applied for exceeded 52,500 cases, but did not exceed 55,000 cases of salmon, fortyeight pounds to the case. Those of the twenty-second class 
are canners whose pack for the year next preceding the year the license is applied for exceeded 55,000 cases, but did not exceed 57,500 cases of salmon, forty-eight pounds to the case. Those of the twenty-third class are canners whose pack for the year next preceding the year the license is applied for exceeded 57,500 cases, but did not exceed 60,000 cases of salmon, fortyeight pounds to the case. Those of the twenty-fourth class are canners whose pack for the year next preceding the year the license is applied for exceeded 60,000 cases, but did not exceed 65,000 cases of salmon, forty-eight pounds to the case. Those of the twenty-fifth class are canners whose pack for the year next preceding the year the license is applied for exceedech 65,000 cases, forty-eight pounds to the case. When more than one cannery or plant is operated by the same person, firm, or corporation, each shall be licensed separately and according to its class. Any person, firm, or corporation desiring to engage in the business of canning salmon in this State shall make an application in writing to the Master Fish Warden for a license therefor, which application shall describe the location of the salmon cannery, as near as practicable, and shall be accompanied by the affidavit of the applicant, stating the number of cases of salmon that were packed in such cannery the year next preceding the year the license is to be issued, and shall deposit with said application the license fee, according to the class in which said cannery should be listed. No license shall be issued until such affidavit is made and filed and such license fee paid; provided, that if any person, firm, or corporation desires to obtain a license for a cannery which had not been operated the year preceding such application, such cannery shall, upon application, be classed by the Board of Fish Commissioners, and the license fee to be paid shall be three times the regular fee according to that class; excepting in a case where a cannery remained idle only one season, then in that case the license fee to be paid shall be double the regular fee. All licenses issued under the provisions of this section shall be good only in the district for which the same is issued, and shall expire on the thirty- 
first day of March following the issuance of such license. [L. 1905, p. 116, § 2.]

\section{Dealers Classified-License Fees to be Paid.}

Any person, firm, or corporation engaged in the business of buying, selling, packing, preserving, or otherwise dealing in salmon fish or sturgeon, other than canning thereof, which is herein provided for, and whether said person, firm, or corporation catches his or their or its own salmon fish or sturgeon or not, shall be and are classified as follows: First class dealers, handling less than three tons of fish per year; second class dealers, handling three to six tons of fish; third class dealers, handling six to ten tons of fish; fourth class dealers, handling ten to fifteen tons of fish; fifth class dealers, handling fifteen to twenty tons of fish; sixth class dealer's, handling twenty to twenty-five tons of fish; seventh class dealers, handling twenty-five to thirty tons of fish; eighth class dealers, handling thirty to forty tons of fish ; ninth class dealers, handling forty to fifty tons of fish ; tenth class dealers, handling fifty to sixty tons of fish; eleventh class dealers, handling sixty to seventy tons of fish; twelfth class dealers, handling seventy to eighty tons of fish; thirteenth class dealers, handling eighty to one hundred tons of fish; fourteenth class dealers, handling one hundred to one hundred and forty tons of fish; fifteenth class dealers, handling one hundred and forty to one hundred and seventy-five tons of fish; sixteenth class dealers, handling one hundred and seventy-five to two hundred and twenty-five tons of fish; seventeenth class dealers, handling two hundred and twenty-five to three hundred tons of fish; eighteenth class dealers, handling three hundred to four hundred tons of fish; nineteenth class dealers, handling four hundred to five hundred tons of fish; twentieth class dealers, handling five hundred to six hundred tons of fish ; twenty-first class dealers, handling six hundred to seven hundred tons of fish; twenty-second class dealers, are those who handled over seven hundred tons of fish of the dressed product. Any person, firm, or corporation desiring to obtain 
a license for the purpose of engaging in the business of buying, packing, selling, preserving, or otherwise dealing in salmon fish or sturgeon, or other than canning thereof, which is herein provided for, and whether said person, firm, or corporation catches his or their or its own salmon fish or sturgeon or not, shall file with the Master Fish Warden an application therefor describing with convenient certainty the locality at which the applicant proposes to engage in business, and the general character of such business, whether cold storage or otherwise, and shall accompany such application with an affidavit of the applicant stating the total number of tons of salmon fish or sturgeon handled by such applicant the year next preceding the year the applicant desires the license, and shall deposit with the Master Fish Warden the license fee as hereinafter provided. Such persons aforesaid of the first class shall pay a license fee of $\$ 5.00$; of the second class, $\$ 7.50$; of the third class, $\$ 10$; of the fourth class, $\$ 15$; of the fifth class, $\$ 20$; of the sixth class, $\$ 25$; of the seventh class, $\$ 30$; of the eighth class, $\$ 40$; of the ninth class, $\$ 50$; of the tenth class, $\$ 60$; of the eleventh class, $\$ 70$; of the twelfth class, $\$ 80$; of the thirteenth class, $\$ 100$; of the fourteenth class, $\$ 125$; of the fifteenth class, $\$ 160$; of the sixteenth class, $\$ 200$; of the seventeenth class, $\$ 270$; of the eighteenth class, $\$ 360$; of the nineteenth class, $\$ 50$; of the twentieth class, $\$ 540$; of the twenty-first class, $\$ 630$; of the twenty-second class, $\$ 800$; provided, that any person, firm, or corporation desiring a license that, during the year preceding such application was not engaged in dealing in salmon fish or sturgeon as a packer by the cold storage process or otherwise shall, upon application, be classified by the Board of Fish Commissioners, and the license fee to be paid shall be three times the regular fee, according to the class named; excepting in a case where a cold storage plant remained idle only one season, then and in that case the license fee to be paid shall be double the regular fee. Persons desiring to engage in the business of retailing salmon fish or sturgeon for home consumption, or peddling such fish from house to house, shall be listed of the first class, and shall pay 
a license therefor accordingly, whether said person caught his own salmon fish or sturgeon or not. Where more than one shop or plant is operated by the same person, firm, or corporation, each shall be licensed separately and according to its class. A peddler's license shall be good for one person or wagon, and no more. All licenses issued under the provisions of this section shall be good only in the district for which the same is issued, and shall expire on the thirty-first day of March following the issuance of such license. [L. 1905, p. 119, § 3.]

8 4096. Record of License Applications to be Kept by Fish Warden Authority to Inspect Canneries, Places of Business, and Books-Appeals.

The fish warden shall keep and preserve a record of all applications for license filed. The fish warden is not bound by statements therein made as to the amount of fish packed or handled, but for the purpose of ascertaining the true class in which any cannery or dealer in salmon fish or sturgeon, as herein provided, should be listed, such fish warden or any of his deputies has full authority and is hereby authorized to inspect the cannery and places of business of such parties, and the books of such parties showing the amount of their pack or the amount handled (but the information derived therefrom shall not be made public), and if in the opinion of the fish warden the facts set forth in the affidavit of the applicant for a license are untrue, and the canner, packer, or dealer, as herein provided, is not properly classed, he shall immediately class the same and list the same properly, and cancel the license already issued, and demand from such canner, packer, or dealer, as herein specified, a new license fee necessary to bring it within the class it should have been listed in in the first instance; but any person, firm, or corporation feeling aggrieved by the decision of the fish warden may appeal from the decision of the fish warden to the circuit court of the State of Oregon for the county in which his or its business is situated. Such appeal is taken by serving a written notice of such appeal on the fish warden, or his deputy residing in the county, and filing same with proof of service indorsed thereon within ten 
days from receiving notice of such relisting by such fish warden, together with a bond with one or more sufficient sureties, to be approved by the clerk of the circuit court, conditioned to pay whatever judgment may be rendered against him on the appeal, in the office of the clerk of the circuit court of the State of Oregon for the county in which said business is located; and the case shall be tried in the said circuit court as a suit in equity, and judgment entered by the court accordingly, and the decision shall be final, and the judgment of the court shall be enforced as other judgments are, and shall have like force and effect. No costs shall be taxed against the fish warden in any event. Nothing in this section shall be construed to prevent the Board of Fish Commissioners, or any one of the deputies, from giving in evidence at the trial of such appeal any fact or information derived by them from inspection of the books or papers of any canner, packer, or dealer in fish, or from offering in evidence in any court the affidavit of any person required by this act. [L. 1901, p. 342, § 35.]

\section{\$4097. License, Dated, Numbered, and What to Contain.}

Each and every license issued under the provisions of this act shall be numbered and dated by the fish warden, and the number of cannery, dealer, pound net, gill net, drift net, fish wheel, seine, trap, or other appliance, or business licensed, and the number of the district where the appliance or business is located, and shall also contain the name of the person or persons to whom such license is granted. All licenses for whatever appliance or business granted under the provisions of this act shall be valid only in the district for which it is issued, and shall expire and become null and void on December 31 of each year. [L. 1903, p. $236, \S 13$.

By act of the Legislature of 1905 (L. p. 116), that portion of this section relating to the expiration of licenses is amended, making all such licenses expire on the thirtyfirst day of March following their issuance. See 8 4093, as amended, this publication.

\section{Certificate Sufficient Proof of Issuance.}

That in all prosecutions requiring proof as to the issuance or nonissuance of a license by the Master Fish Warden under any of the laws of this State, the certificate of the Master Fish 
Warden as to the issuance or nonissuance of such license by him shall be sufficient proof on that question to establish the fact, and such certificate shall be admitted in evidence as to the issuance or nonissuance of such license in any prosecution. [L. 1905, p. $206, \S 1$.]

\section{; 4098. Regulations to Govern Fixed Fishing Appliances.}

Any person, after first having obtained license from the fish warden to operate a pound net, trap, or weir, shall indicate the location for such pound net, trap, or weir by erecting a permanent and conspicuous monument on the bank of the river or channel, and upon said monument shall cause to be placed and maintained the license number, preceded by an " $O$," designated by the fish warden at the time of issuing said license; said number to consist of black figures not less than six inches in length painted on white ground; after any such pound net, trap, or weir has been located and constructed the owner thereof shall file a map with the fish warden, giving the exact description and location thereof. During the fishing season, between sunset and sunrise, a bright and conspicuous white light shall be maintained on each pound net, trap, or weir. Any person having obtained a license from the fish warden to operate a fish wheel, shall cause to be placed and maintained in a conspicuous place on said wheel or on a permanent monument erected for that purpose the number, preceded by an "O," designated by the fish warden at the time of issuing said license; said number to consist of black figures not less than six inches in length painted on white ground. Any person having obtained a license from the fish warden to operate a set net shall cause to be placed and maintained on a substantial post or monument erected for that purpose on the bank of the river or channel, or upon a buoy securely anchored on the location claimed, the number, preceded by an "O," designated by the fish warden at the time of issuing said license, said number to consist of black figures not less than six inches in length painted on white ground; in addition thereto said person shall cause to be branded on the corks of each end of said 
set net, and upon the cork nearest the center thereof the number designated in said license, said number to consist of figures not less than one inch in length. Any person having obtained a license from the fish warden to operate a seine shall cause to be placed and maintained in a conspicuous place on the wharf, scow, or float maintained at the seining ground claimed, the number, preceded by an "O," designated by the fish warden at the time of issuing said license, said number to consist of black figures not less than six inches in length painted on white ground; in addition thereto said person shall cause to be branded on the corks of each end of said seine, and upon the cork nearest the center thereof, the number designated in said license, said number to consist of figures not less than one inch in length. Any person having obtained a license from the fish warden to operate a gill net in any of the waters of this State or the Columbia River, or from the fish commissioner of the State of Washington, said State having concurrent jurisdiction on the Columbia River with this State as to gill nets and as to gill net fishermen, shall cause to be placed upon the corks of each end of such net, and upon the cork nearest the center thereof, the number designated in said license, said number to consist of figures not less than one half inch in length; and shall also cause to be placed upon each side of the bow of the boat used to operate such net, the number designated in said license, preceded by an "O," if issued by the fish warden of the State of Oregon, or the number designated in said license, preceded by a "W," if issued by the fish commissioner of the State of Washington, said number to consist of black figures not less than six inches in length painted on light ground, or white figures not less than six inches in length painted on dark ground. A separate license shall be required for each pound net, trap, weir, fish wheel, set net, or for any other fixed appliance, and for each seine, gill net, or other drift net. Any owner or operator of any fishing appliance or boat herein specified, who fails, neglects, or refuses to comply with any of the provisions of this section within five days from the date of license issued 
for such appliance, shall be deemed guilty of a misdemeanor, and upon conviction thereof shall be punished by a fine of not less than $\$ 10$ nor more than $\$ 50$ and the costs of the action; a failure from day to day to comply with any of the provisions of this section shall constitute a separate offense and subject the owner or operator of said appliance or boat to additional punishment by such fine. [L. 1905, p. 429, § 4.]

\section{Pound Net - Duty of Owner.}

That it shall be the duty of the owner of each and every pound net constructed in the waters of the Columbia River, over which the State of Oregon has concurrent jurisdiction, to remove from the bed of the Columbia River all piling driven in the same, by pulling out said piling, within five days from the close of each fall fishing season, and to keep said piling out of the river until within ten days of the commencement of the fishing season in the following spring. [L. 1905, p. 271, § 1.]

\section{Violation of Preceding Section-Penalty.}

That any person who shall violate any of the provisions of this act, upon conviction thereof, shall be punished by a fine of not less than $\$ 50$ nor more than $\$ 500$, or by imprisonment in the county jail not less than twenty-five days nor more than two hundred and fifty days, or by both such fine and imprisonment. [L. 1995, p. 271, \& 2.]

\section{Fish Warden to Keep Books and Devote Entire Time to His Office.}

The fish warden shall keep proper books showing the licenses issued, to whom issued, and amounts received, and all moneys disbursed and paid out for any cause. It shall aiso be his duty to devote his entire time and attention to the fishing interests and fishing industries of the State; and see that all laws for the protection, preservation, and propagation of all food fishes, and oysters and shellfishes, in the waters and streams of this State are enforced. [L. 1901, p. 344, § 38.] FISHERIES- 3 


\section{\&4100. Annual Report of Warden and Suggestions to Board.}

Said fish warden shall annually, on December 1 , report to the Board of Fish Commissioners of this State a full account of his actions, also of the operations and results of the law pertaining to fish and shellfish industries, the method of taking fish, the number of young fish hatched and where distributed, amount of expense incurred, and make suggestions as to the needs to further legislation, if any, and full statistics of the fishing and shellfish industries, and amount of all money received and disbursed. [L. 1901, p. 344, § 39.]

\section{\% 401. Arrests, Authority of Warden and Doputies to Make Without Process - Resistance a IMisdemeanor.}

The fish warden or his deputies shall have authority to arrest without writ, rule, order, or process any person or persons detected by him or them in the act of committing a crime in violation of the fish laws of this State; and they are hereby made peace officers of this State for that purpose, and shall have authority to execute all criminal process issued for the arrest or detention of any person complained against for the violation of any of the fish laws of this State. Any person. who knowingly or wilfully resists or opposes such officer in discharge of his said duties shall be deemed guilty of a misdemeanor, and upon conviction thereof, shall be punished as in this act hereinafter provided.

[L. 1901, p. 344, § 40 .]

84102. Inspection of Canneries, Cold Storage Houses, etc., by Warden.

The fish warden is hereby authorized to inspect all canneries, cold storage houses, boats, nets, wheels, traps, and other fishing apparatus, and all property used in the catching and packing of fish, for the purpose of enforcing the provisions of this act, and to that end said fish warden is authorized to enter into said property and make inspection thereof. [L. 1901, p. 345, § 41.]

84103. Attorney General, Commissioners May Require Advice From - Prosecuting Attorneys to Act on Complaint of Board.

The Board of Fish Commissioners shall have the authority to apply to the Attorney General for his official opinion upon 
any question touching the construction and interpretation of the statutes and the duty of the Board of Fish Commissioners wherein they shall need legal advice; and it shall be the duty of the prosecuting attorneys of the several districts to prosecute in their respective districts, on information and complaint of such Board of Fish Commissioners, fish warden, or any of his deputies, any person violating any of the provisions of this act. [L. 1901, p. 345, \& 42.]

\section{Salary and Expenses of Wardens, How Audited and Paid.}

The salaries of the fish wardens, and the necessary expenses incurred by them in the performance of their duties, and all the expenses incurred under the provisions of this act, shall be audited by the Board of Fish Commissioners, upon bills being presented properly certified by the fish wardens; and the Secretary of State shall, upon the approval of such bills, draw his warrant upon the State Treasurer in payment of the same from the general fund. [L. 1901, p. 345, \& 43.]

\section{Fish Commissioners Shall Receive Only Expenses.}

Said Board of Fish Commissioners shall receive no compensation for their services as such board, but shall be allowed necessary actual traveling expenses. All accounts for expenditures incurred or made pursuant to the provisions of this section shall be audited and approved by said commission before presentation to the Secretary of State. [L. 1901, p. $345, \S 44$.]

\section{\$4106. Fish Commissioners May Propagate Food Fishes - Authority of in so Doing.}

The Board of Fish Commissioners is authorized by this act to propagate and stock the various waters and streams of this State with salmon, sturgeon, trout, or other food fishes, not inimical to or destructive of salmon; and for the purpose of protecting the same they are hereby authorized to close any stream or any designated portion thereof in this State frequented by salmon, or any stream which they have stocked, and prevent any person taking or fishing for or catching any salmon or 
food fishes therein. Should the Board of Fish Commissioners desire to close any stream or designated portion thereof frequented by salmon, or any stream or designated portion thereof which they have stocked with food fish, they shail cause notice thereof to be filed in the office of the county clerk in each county in which such stream or designated portion thereof lies, and shall publish such notice in some public newspaper published at the county seat in such county or counties for four successive weeks. Such notice shall designate as nearly as practicable the streams or designated portion thereof to be closed, and shall state that on and after a date therein stated it will be unlawful to fish for or take or catch any salmon or other food fishes therein (which date shall not be less than thirty days from the date of the first publication), and shall cause like notices to be published for such time in three collspicuous places on the banks of such streams or designated portion thereof. Upon the completion of the publication of such notice, the same, with proof of the publication and posting thereof, shall be filed with the original notice in the office of the county clerk, and it shall be unlawful at any time after the expiration of the date specified in said notice for any person to fish for, catch, or take any salmon, or any food fishes stocked therein, until notice shall be filed and likewise published by the Board of Fish Commissioners of the opening of such stream or designated portion thereof to the public for fishing. [L. 1901, p. 345, \& 45.]

84107. Placing Wish in Water Without Authority of Board Unlawful.

It shall be unlawful for any person, without written authority from the Board of Fish Commissioners, to place in any water of this State any species or variety of fish whatever. [L. 1901, p. 346, § 46.]

\section{'4108. Justices' Courts Have Concurrent Jurisdiction.}

Justices of the peace shall have concurrent jurisdiction with the circuit courts of this State of all offenses mentioned in this act. [L. 1901, p. 346, § 48.] 


\section{Fish May be Taken by Proper Officers For Propagation at Any Time.}

Nothing in this act shall be construed so as to prevent the taking of salmon at any time of the year by the Board of Fish Commissioners or accredited officers of the United States Government, for propagation.

[L. 1901, p. 346, § 49.]

\section{Fish Appliances Liable to Execution for Fines.}

Any and all gear and appliances used in violation of the provisions of this act, including boats, traps, nets, weirs, fish wheels, or other appliances, shall be subject to execution for the payment of fines and costs herein provided for. [L. 1901, p. 346, § 50.]

\section{Fishing Without License or Otherwise Unlawfully, Subjects Appliances to Seizure-Procedure Thereon.}

All fish traps, pound nets, gill nets, set nets, fish wheels, fishing boats, and vessels used in fishing, and apparatus, and any and all appliances or devices which shall be used or employed by any person or persons or corporations, including all such fishing appliances fished or operated by any person who has not obtained a license, or a license to operate such appliance, in fishing for or catching salmon fish at or during any time or in any of the waters in this act prohibited, and which by this act is made unlawful, whether being operated by any person or left in a condition to take fish, or abandoned but left in a condition to take fish, shall be seized and be confiscated, condemned, and sold, and the proceeds of such sale shall be paid to the State Treasurer, and by him deposited in the hatchery fund for the district in which such appliance is seized; and it is hereby made the duty of the fish warden to seize and take into his possession all such fishing appliances hereinbefore mentioned, which shall be operated wrongfully or unlawfully by any person, or left by any person in a condition to take fish, or abondoned by any person but left in a condition to take fish, shall be seized and be confiscated, condemned, and sold, and the proceeds of such sale shall be paid to the State Treasurer and by him deposited in the hatchery 
fund for the district in which snch appliance is seized; and it is hereby made the duty of the fish warden to seize and take into his possession all such fishing appliances hereinbefore mentioned, which shall be operated wrongfully or unlawfully by any person, or left in a condition to take fish, $\mathrm{Or}^{*}$ abandoned by any person but left in a condition to take fish, at or during any time or in any of the waters in this act prohibited, and which is made unlawful by this act; and immediately upon such seizure the prosecuting attorney for the district in which such appliance is seized shall institute an action in the circuit court for that county to have such appliance confiscated, condemned, and sold ; such petition shall contain a true description of the appliance sought to be confiscated, condemned, and sold, as nearly as practicable, together with all marks, brands, or any special features thereof, calculated to designate same from other appliances of like nature, and, if a fixed appliance, the number ; and shall allege facts showing that the same was used in violation of the provisions of this act. The petition shall be duly verified by the oath of the fish warden, or one of the deputies, and in such action the State of Oregon shall be plaintiff, and the owner of such appliance, if known, shall be the defendant; and if unknown, then such unknown owner shall be designated as "John Doe," whose true name is unknown; and such like proceedings shall be had and such action shall be prosecuted to final determination as in actions at law, excepting that the summons shall be issued by the clerk of the court, and shall require the defendant, if known, to appear and answer within fifteen days after the service of such summons upon him, and if he fails so to appear and answer, judgment of confiscation shall be entered as prayed for in the petition. Such summons shall contain a brief description of the appliance sought to be confiscated; and if such defendant shall be unknown or can not be found, the summons shall require such unknown owners to appear within four weeks after the first publication thereof, as hereinafter provided; such summons shall be served upon the defendant, if known, personally in 
any county in the State; and if unknown and can not be found, the summons shall be published for four weeks in some newspaper published in the county where the action is instituted. All persons owning or claiming any interest in such fishing appliance will be permitted to answer, setting forth their various interests, but it will be no defense to a judgment of confiscation that the owner or mortgagee or lienor of such appliance did not consent to have the same unlawfully operated. Upon the trial of said cause the matter to be determined shall be whether or not the appliance seized was unlawfully employed, or suffered or permitted to be unlawfully employed, in violation of the provisions of this act, or used or operated without a license or by one not licensed; and if judgment shall be entered, that the same was used or employed, or suffered or permitted to be used or employed, in violation of this act, a judgment shall be rendered confiscating each appliance and ordering the same to be sold at public auction to the highest bidder for cash, and execution shall issue upon such judgment as in an ordinary action at law, and like proceedings shall be had under such execution as now provided by law. The money arising from the sale of such appliance shall be immediately deposited with the State Treasurer, and by him deposited in? the hatchery fund for the district in which such appliance was seized. No fee shall be charged or collected from the Board of Fish Commissioners at the institution or during the prosecution of such action, and no judgment shall be awarded against them or the State of Oregon for costs and disbursements. Should the Board of Fish Commissioners deem themselves aggrieved by the ruling or decision of the court at any time after the institution of said action, the right of appeal is hereby given the State of Oregon, to be prosecuted in the same manner as appeals in ordinary civil actions, excepting that no fee shall be charged the State and no bond shall be required on appeal. [L. 1901, p. 347, § 51.] 


\section{The Term "Person" or "Persons," What to Include.}

The term "person" or "persons"' used in this act shall be deemed to include partnerships and corporations. [L. 1901, p. $349, \S 52$.

\section{Penalty for Violating Provisions of Act.}

Any person or persons violating any of the provisions of this act shall be deemed guilty of a misdemeanor, and upon conviction thereof shall be punished by a fine of not less than $\$ 50$ nor more than $\$ 1,000$, and the costs of the action, or by imprisonment in the county jail not less than twenty-five days nor more than one year, or by both such fine and imprisonment; provided, in case of fine only that he be imprisoned in the county jail until such fine and costs of action be paid, he shall be credited on such fine and costs the sum of $\$ 2.00$ for each day of imprisonment. In all actions for violations of the provisions of this act one third of the moneys collected as fines shall be paid to the District Attorney, or his deputies, who conducts the action; one third shall be paid to the informer or prosecuting witness; provided, such informer or prosecuting witness is not a regularly appointed and salaried fish warden, or salaried deputy warden; the remaining one third or two thirds, or all, as the case may be, shall be paid to the Master Fish Warden and by him deposited with the State Treasurer, to be placed in the "hatchery fund" for the district in which said fine was imposed. [L. 1903, p. 237, \& 15.]

\section{Sturgeon.}

Repealed.

This section is repealed by act of 1905 (L. p. 277 ). The substance of the section is con. tained in 84061 , as amended, 1905 (L. p. 238).

\% 415. Young Sturgeon, Unlawful to Take in Columbia River - Penal Provision.

It shall be unlawful at any time to take or kill any young sturgeon under four feet in length, or fish for the same with any device or appliance whatever in the waters of the State of Oregon, or in the waters of the Columbia River or its tributaries; and any person or persons fishing with a trap, weir, 
pound net, gill net, set net, fish wheel, seine or any other fishing apparatus in the waters of the State of Oregon, or in the waters of the Columbia River or its tributaries, who, on lifting, drawing, taking up, or removing any trap, weir, pound net, gill net, set net, fish wheel, seine, or other fishing apparatus, shall find young sturgeon under four feet in length entangled or caught therein, shall immediately, with care and the least possible injury to the fish, disentangle and release the same and transfer the fish to the water without violence. Any person or persons, firm or corporation, violating any of the provisions of this section, or receiving or having in his or their possession for consumption, sale, or transportation, or sells or offers for sale or for transportation, or tranports young sturgeon under four feet in length, shall be deemed guilty of a misdemeanor, and upon conviction thereof shall be punished by a fine of not less than $\$ 20$ and not more than $\$ 1,000$ and costs of the action, or by imprisonment in the county jail not less than ten days nor more than one year, or by both such fine and imprisonment; provided, in case of fine only, that he be imprisoned in the county jail until such fine be paid, and he shall be credited on such fine the sum of $\$ 2.00$ for each day imprisoned. All moneys collected as fines shall be disposed of as follows: One third shall be paid to the prosecuting witness other than the Master Fish Warden or the deputy fish warden; the remaining two thirds, or all, as the case may be, shall be paid to the Master Fish Warden, and by him deposited with the State Treasurer, to be placed in the hatchery fund for the district in which said fine was imposed. In all prosecutions under this section the possession by any person or persons, firm or corporation, of young sturgeon under four feet in length shall be construed as prima facie evidence that the same was taken from the waters of the State of Oregon, or from the waters of the Columbia River or its tributaries. [L. 1905, p. 278, § 2.] 
\% 4116. Chinese Sturgeon Lines, Use of Prohibited in Columbia River - Fish Commissioner to Destroy - Penal Provision.

It shall be unlawful to cast, extend, set, use, or continue or assist in casting, extending or using, any Chinese sturgeon line, or lines of a similar character, in the waters of the State of Oregon, or in the waters of the Columbia River or its tributaries. The fish warden and any of his deputies or bailiffs, sheriffs, deputy sheriffs, constables, or other peace officers, are hereby authorized to seize and destroy any such lines found in said waters, and they are hereby authorized to arrest, without warrant, any person or persons detected in setting or using any Chinese sturgeon line or lines of a similar character in said waters. Any person or persons violating any of the provisions of this section shall be deemed guilty of a misdemeanor, and upon conviction thereof shall be punished by a fine of not less than $\$ 20$ and not more than $\$ 1,000$ and costs of the action, or by imprisonment in the county jail not less than ten days nor more than one year, or by both such fine and imprisonment; provided, in case of fine only, that he be imprisoned in the county jail until such fine and costs of action be paid, and he shall be credited on such fine and costs the sum of $\$ 2.00$ for each and every day imprisoned. All moneys collected as fines shall be disposed of as follows: One third shall be paid to the prosecuting witness other than the Master. Fish Warden or the deputy fish warden; the remaining two thirds, or all, as the case may be, shall be paid to the Master Fish Warden, and by him deposited with the State Treasurer, to be placed in the hatchery fund for the district in which said fine was imposed. [L. 1905, p. $279, \S 3.1$

\section{FISH WAY OVER THE FALLS AT OREGON CITY.}

\section{Appropriation For.}

That there be and hereby is appropriated out of any moneys in the State treasury, not otherwise appropriated, the sum of five thousand $(\$ 5,000)$ dollars, or so much thereof as shall be necessary, to construct a fish way over the falls of the Willamette River, at Oregon City. [L. 1903, p. 307, § 1.] 


\section{Location of Fish Way, How Determined.}

Said fish way shall be constructed in the bed of the river at such point along said fall as may be determined by the Board. of Fish Commissioners of the State, by making excavations in the solid rock and building such superstructure as will be necessary, so that the slope will be more gradual and a series of pools formed connecting with each other, all constructed and arranged in such a manner that salmon can freely ascend from below to above the falls by passing from pool to pool. [L. 1903, p. 307, § 2.]

\section{Board of Fish Commissioners to Award Contract.}

The plans, location, and construction of said fish way shall be under the control and direction of the said Board of Fish Commissioners, which board is hereby authorized, at its discretion, to purchase tools and supplies, and employ a superintendent and workmen to construct the same, or advertise and award contract or contracts for the construction of said fish way. Said construction shall begin as soon as practicable after the approval of this act. [L. 1903, p. 307, \&3.]

\section{Board to Draw Warrants.}

All expenses of whatever nature incurred by said board under the provisions of this act shall be paid upon properly certified bills being presented, and the Secretary of State shall, upon the approval of such bills by said board, draw his warrant upon the State Treasurer in payment of the same from the general fund. [L. 1903, p. 307, §4.]

\section{MIay Remove All Obstructions.}

In order to construct said fish way, said board, its employés and agents, are hereby authorized to remove all obstructions, whether natural or artificial, to the construction of said fish way or the passage of fish over said falls, and to remove any natural or artificial obstructions placed in the river above the falls which would prevent the free passage of fish up the river. [L. 1903, p. 307, \&5.] 


\section{Care After Completion.}

After said fish way is constructed it shall be under the care of said board, which shall make any extension, additions, alterations, or repairs to the same that shall become necessary, and any unexpended part of said sum herein appropriated shall be available for such purposes. [L. 1903, p. 307. § 6.]

\section{Hindering Passage of Fish Prohibited.}

It shall be unlawful for any one to hinder, annoy, or disturb the fish entering, passing through, or leaving said fish way, or to obstruct the passage of fish through the same at any time or in any manner, or for any one to place anything in said fish way or use any devise for catching fish, or any wheel, or net, or hooks, or lines in said fish way, or anywhere within fifty feet thereof, or to catch fish at any time anywhere within fifty feet of said fish way, or any one to do any injury to said fish way. [L. 1893, p. 37, \& 8.]

The concluding sentence of the act of 1901, (L. p. 337,8 , ) amends this section to read "within six hundred feet of said fishway." See 4085 , this publication.

Following is an opinion of the Attorney General, construing 838085 and 4118, rendered at the request of the Master Fish Warden:

SALEM, Oregon, December 17, 1901.

DEAR SIR: Replying to yours of the $2 d$ instant requesting my opinion as to how near to the fish way recently built by the State over the falls of the Willamette River at Oregon City, people are allowed under the law to catch salmon, permit me to say that section 4055 of Bellinger and Cotton's Annotated Codes and Statutes provides: "It shall be unlawful for any person to wilfully or knowingly destroy, injure, or abstract from such fish way (those mentioned in the act) or to take or catch any salmon or other migratory fish within six hundred feet of any fish way."

"Any fish way" means a fish way built by the State as well as one built by private parties. Any person who violates the provisions of the section above referred to is punishable under section 4113 , as amended by laws of 1903 , page 237 . The law of $1893,1 \mathrm{am}$ inclined to think, is applicable, except where they conflict with the $1901 \mathrm{law}$, as the former was enacted with reference to a fish way to be constructed by the State of Oregon at Oregon City, and while it was not done under that act, it was constructed by virtue of a second act, and the penalties for obstructing the same were not repealed. Horvever, the distance that salmon or other migratory fish may be taken from the fish way is governed by the law of 1901, that being the later act, and any person who injures the fish way in any manner can be punished under the former statute, or other statutes relative to injuries to property.

Respectfully,

A. M. CRAWFORD,

Attorney General.

\section{Penalty For Violation of Act.}

Any person violating any of the provisions of this act shall be guilty of a misdemeanor, and upon conviction shall be punished by a fine of not less than $\$ 20$ nor more than $\$ 200$, or by 
imprisonment in the county jail not less than ten days nor more than one hundred days, or both, in the discretion of the court. [L. 1893, p. 37, § 9.]

See \& 4113 as amended 1903 (L. p. 237, ₹ 15).

\section{4120. Justices' Courts Have Concurrent Jurisdiction.}

Justices of the peace shall have concurrent jurisdiction in the first instance with the circuit courts of all offenses under this act. [L. 1893, p. $37, \S 10$.

\section{4121. Authority to Remove Obstructions Above Falls.}

The board provided for in section 3 shall have authority to remove any artificial obstructions placed in the river above the falls which would prevent the free passage of fish up the river. [L. 1893, p. 37, § 11 .

The board referred to in this section, as provided for in section 3 of the act, consists of the Governor, Secretary of State, and State Treasurer. Section 3 is temporary in its operation, and is therefore omitted. The board created by that section continues in existence for the purpose specified in section 4121 .

Fire, Game, and Fish Wardens, ex officio.

That from and after the passage of this act the sheriffs and deputy sheriffs of the counties and constables of the various precincts and districts of the State of Oregon shall be and hereby are created ex officio fire, game, and fish wardens. [L. 1903, p. $140, \S 1$.

\section{Duties of Wardens.}

It shall be the duty of said fire, game, an fish wardens to enforce all statutes of the State now in force, or that may hereafter be enacted, for the protection of forests and timber lands from fire, and for the protection of game, game birds, game mammals, song and insectivorous birds, and fish, and for the protection of chinook, silverside, steelhead, and all other anadromous species of salmon and other fish; and said sheriffs, deputy sheriffs, constables, or wardens shall have authority to arrest, without warrant, any person or persons caught by them in the act of violating any of the aforesaid laws for the protection of forests and timber lands, game and food and game fish, and take such person or persons forthwith 
before a justice of the peace, or other magistrate having jurisdiction, who shall proceed without delay to hear, try, and determine the matter. Such arrests may also be made on Sunday, in which case the person or persons arrested shall be taken before the proper officer, and proceeded against as soon as may be on a week day following the arrest. [L. 1903, p. 140, $\S 2$.

\section{Power to Search Without Warrant.}

Said sheriffs, deputy sheriffs, constables, or wardens shall have power, without warrant, to search and examine any boat, conveyance, vehicle, fish box, fish basket, game bag, or game coat, or other receptacle for game or fish, when they have good reason to believe that any of the laws for the protection of forests and timber lands, game and food fish, have been violated; and the said sheriffs, deputy sheriffs, constables, or wardens shall at any time seize and take possession of any and all birds, animals, or fish which have been caught, taken, or killed at any time in a manner or for a purpose, or had in possession or under control, have been shipped or about to be shipped, contrary to any of the laws of this State; and seize and take possession of any and all fishing appliance and boats fished, operated, or maintained in violation of any of the game or fish laws of the State. Any court having jurisdiction of the offense, upon receiving proof of probable cause for believing in the concealment of any bird, animal, or fish, caught, taken, killed, had in possession, under control or shipped, or about to be shipped, contrary to the law, shall issue a search warrant, and cause a search to be made in any place, and to that end may, after demand and refusal, cause any building, inclosure, or car to be entered, and any apartment, chest, box, locker, crate, basket, or package to be broken open and the conteuts thereof examined by any said sheriff, deputy sheriff, constable, or warden. All birds, animals, or fish, or nets or fishing appliance or apparatus, seized by any sheriff, deputy sheriff, constable, or warden shall be disposed of in such manner as may be directed by the court before whom the offense is tried, 
and such sheriff, deputy sheriff, constable, or warden shall not be liable for damages on account of any search, examination, or seizure, or the confiscation of any nets or fishing appliance or apparatus of any kind in accordance with the provisions of this act. [L. 1903, p. 141, \& 3.]

\section{Additional Fees from Fines.}

Any sheriff, deputy sheriff, constable, or warden, as informer or prosecutor, upon the arrest and prosecution of any offender to conviction under the provisions of this act, shall, in addition to the fees to which he may be entitled under existing laws, be entitled to receive one third of the money collected as fines in such action. [L. 1903, p. 141, § 4.]

\section{Violations-Returns of Officers-Penalty.}

Each of the said sheriffs, deputy sheriffs, constables, or wardens shall, for the purpose of this act, have concurrent jurisdiction throughout his own proper county; and they shall in the first week of each term of the circuit court of their respective counties, make special returns to said court, under oath, of all violations occurring in their respective counties or districts, or which may come or be brought to their notice, of any of the provisions of any law now in force, or that may hereafter be enacted for the protection of the forests and timber lands, game, and fish; and it shall be the duty of the judge of said court to see that such returns are faithfully made, and any sheriff, deputy sheriff, constable, or warden wilfully neglecting or refusing to make such returns, or to prosecute any offense under said laws of which he shall have personal knowledge, or of which he shall have notice in writing by any citizen, giving the name of the offender, together with the names of the witnesses, shall be deemed guilty of a misdemeanor, and upon conviction thereof shall be sentenced to pay a fine of $\$ 50$, or to undergo an imprisonment in the county jail of two months, both or either, at the discretion of the court. [L. 1903, p. 142, \& 5.] 


\section{OYSTER BEDS: PROPAGATION AND GATHERING.}

\section{\% 4122. Natural Oyster Beds Free - Artificial Beds Private Property.}

The natural beds of oysters on the waters of this State shall be free to all citizens thereof who shall have resided in this State one year, and shall have been residents of the county where such beds are located for a period of six months immediately preceding the time of taking such oysters; but artificial plantations of oysters belonging to citizens of this State, if distinctly marked out by means which shall not obstruct navigation, and not exceeding the extent allowed by local regulations, shall be deemed and protected as private property; and the following portions of Yaquina Bay, in Benton County, are hereby designated and set apart for artificial plantations of oysters, to wit: Brown's Flat, Pool's Slough, Lyman's Eddy, and Green Point; and the size and dimensions of said oyster beds shall remain as they have been fixed by the local regulations of the oystermen's association, not exceeding two acres in any one plantation; and every person holding a claim for the cultivation of oysters shall in all respects comply with the local regulations applicable thereto. [L. 1862, D. Cd. p. 830, $\S 1$; L. 1868, p. 14, § 1; L. 1870, p. 78, \& 1; H. C. $\S 3844$.

\section{Close Season as to Natural Beds.}

No person shall remove oysters from natural beds between the fifteenth day of June and the tenth day of September in any year; provided, that nothing in this chapter shall be so construed as to prevent any person owning artificial beds from taking oysters from said beds at any time. [L. 1864, D. Cd. p. $830, \S 2 ;$ H. C. $\S 3845$.]

\section{4124. Who Privileged to Take Oysters.}

No person not a citizen of the United States or competent to become such under the laws of congress, and actually domiciled within the State, and subject to State and county taxes, shall gather oyster's in natural beds, for sale or transportation or for replanting, nor shall own any artificial oyster bed or any interest therein; nor shall any person purchase oysters 
for transportation or replanting except from persons so qualified. [L. 1862, D. Cd. p. 830, § $3 ;$ H. C. § 3846.$]$

3 4125. Regulations For Taking Oysters From Natural Beds.

No person shall gather or take oysters from natural beds within the waters of this State with a scoop, scrape, drag, or dredge where the water is of a less depth than twenty-four feet at low tide; nor shall any person gathering oysters from natural or artificial beds commit or permit waste by casting young oysters or shells on shore or in places unfavorable to their growth or increase. [L. 1862, D. Cd. p. 830, §4; L. 1868, p. $14, \S 4$; L. 1876 , p. $7, \S 1$; H. C. $\S 3847$.

? 4126. Penalty For Violation of Provisions of Sections 4122, 4123, 4124, and 4125.

Every person who shall be guilty of violating any provision of sections $4122,4123,4124$, and 4125 shall, on conviction thereof, be fined in any sum not exceeding $\$ 1,000$ for every such offense. [L. 1862, D. Cd. p. 830, §5; L. 1870, p. 67, $\S 1 ;$ H. C. $\S 1951$.

\section{PLANTED OYSTERS.}

\section{Unlawful to Gather or Have in Possession.}

From and after the passage of this act it shall be unlawful, for a period of four years, to gather or attempt to gather, to have in possession, or to offer for sale, any eastern, native, or other oyster, or their progeny, that have heretofore or may hereafter be deposited or planted by the State Biologist, or the United States Fish Commission, in the waters of Oregon; provided, that this section shall not apply to the taking, or having in possession any such oysters by said biologist. [L. 1905, p. 203, § 1.]

\section{State Biologist, Duty to Mark Location.}

It shall be the duty of the State Biologist, immediately after such oysters are planted, to designate the place, in such manner as he may deem sufficient, by placing or causing to be placed, stakes, post-buoys, signboards, or other devices, as the condition of the location may admit; provided, however, that 
the extent of any portion of the natural oyster beds of Yaquina Bay, Lincoln County, Oregon, which may now or hereafter be occupied for the purpose of planting eastern, native, or other oyster's, by the State Biologist or the United States Fish Commission, shall not exceed one acre. [L. 1905, p. 204, \& 2.]

UnIawful to Remove or Damage Devices Marking Oyster Beds.

It shall be unlawful for any person or persons to wilfully or milicionsly remove or damage any stakes, post-buoys, signboards, or other devices placed in the water or upon shore for the purpose of designating the place where such oysters are planted. [L. 1905, p. 204, § 3.]

Fenalty for Violating Preceding Sections.

Any person. who shall violate any of the provisions of the foregoing sections of this act, shall, upon conviction, be fined not less than 10 nor more than $\$ 50$, or be imprisoned not less than five days nor more than twenty-five days in the county jail. And it shall be the duty of the State Master Fish Warden, his deputies and water bailiffs, as well as peace officers, to make arrests and institute prosecutions for the violation of this act; and one half of each fine collected shall be paid to the informer. [L. 1905, p. 205, \& 4.]

\section{OYSTER BEDS IN NETARTS BAY.}

\section{Oyster Plantations in Netarts Bay, Regulation of.}

That portion of Netarts Bay, in Tillamook County, Oregon, lying south of the quarter-section line running east and west through the center of section 19, in township 2 south, range 10 west of the Willamette meridian, is hereby designated as natural oyster beds; and that portion of said bay lying north of said quarter-section line is hereby designated and set apart for artificial plantations of oysters; and the sizes of such artificial plantations shall be as fixed by the local regulatins of any oystermen's association now existing or hereafter o be formed on said bay, not exceeding two acres in any one plantation, and every person holding a claim for the cultivation of oysters on said bay shall in all respects comply with the local 
regulations applicable thereto; provided, however, that no person, firm, corporation, or association shall be entitled to locate more than one such claim. [L. 1901, p. 128.]

\section{SALT WATER CRABS.}

\section{Protection of in Waters of Coos County.}

That it shall be unlawful for any person within the county of Coos, State of Oregon, or within or upon the waters thereof, and including all bays, harbors, and inlets of said county, to kill, take, capture, or destroy any greater number than fifty salt water crabs in one day; and it shall be unlawful for any person, firm, or corporation, within said county, or upon the waters thereof, to sell, exchange, or transport outside of said county, or to have in possession, for the purpose of such exchange, sale, or transportation from said county, any of the aforesaid salt water crabs; and it shall be unlawful for any steamboat company, railroad company, express company, or other common carrier, or corporation, or the officers or agents thereof, or any other person, to transport or carry out of said county, or to receive or have in possession for the purpose of such transportation therefrom, any salt water crab, except for the purpose of exhibition or propagation; provided, that this act shall not apply to the canning of salt water crabs within said county or the exportation of the canned product thereof. [L. 1905, p. $312, \S 1$.

\section{Penalty for Violating Preceding Section.}

Any person or persons, or any manager, president, agent, or employé of any firm or corporation, who shall violate, or shall assist in violating any of the provisions of this act, shall be deemed guilty of a misdemeanor, and upon conviction thereof, shall be punished by a fine of not less than $\$ 25$ and the costs of the prosecution, and not more than $\$ 500$, together with the costs $f$ the prosecution, and in default of payment of such fine and costs, shall be imprisoned in the county jail one day for every $\$ 2.00$ of such fine and costs until the whole thereof shall be paid: [L. 1905, p. $312, \S 2$. 

INDEX 



\section{INDEX.}

ALSEA BAY- $\quad$ PAGE

Closed season on

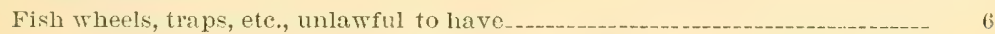

To fish above Gravel Bar unlawful

APPEAL -

From decision of Master Fish Warden, costs____ 29, 30

\section{APPLTANCES-}

Confiseation of - 37

Inspection by Master Fish Warden_____ 31

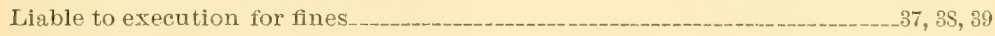

License for

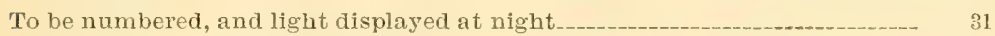

Unlaw ful to be used without license-____- 22

\section{ARREST-}

Authority of Master Fish Warden to make without process_._-____- 34

Resistance, how purished.... 31

ATTORNEY GENERAL-

Board of Fish Commissioners may require legal advice__________

Opinion of, construing sections 1085 and $4118 \ldots \ldots$

\section{BLUEBACK SALMON-}

Possession of, for sale or transportation during closed season probibited _.....

BOATS -

Used by fishermen have to be numbered.

BOARD OF FISH COMMISSIONERS-

Expenses, how andited and paid___________._._. 15, 18

How constituted_-_._._.

May apply to Attorney General for legal advice

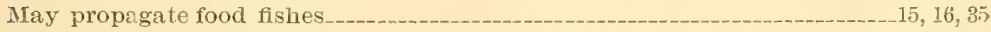

To a udit bills of fish warden and exercise supervisory control over _._._._. 15

Shall receive no compensation_________. 35

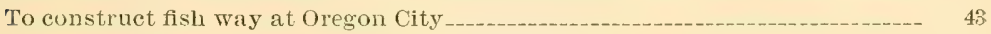

To construet and operate hatcheries in adjoining States_-__-__-_-______-__-_ 17

To make additions, alterations, etc., to fish way at Oregon City____________ 44

Traveling expenses allowed__- 35

Unlawful to place fish of any species or variety in waters of State without authority 


\section{CANNERIES -}

Classitieation

Classification, autbority of Board of Fish Commissioners

Inspection of, by Master Fish Warden

License applications to be kept by Master Fish Warden_._-_-_-_-_-___._-_...-_ 29

License fees to be paid_____- 23

Licuns, what to contain__._._- :30

More than one operated by same person, separate license is required__._-_._-_ 26

Not operated preceding year, what class__________- 26

\section{OHINOOK SALMON -}

Possession of, for sale or trausportation during closed season prohibited

\section{CITIZENS-}

Having declared intentions, fishing restricted to

License from States of Iduho and Washington sufficient, where

\section{COAST STREAMS-}

Cloved reasuln oil

COLD STOPAGE HOUSES-

Innection by Master Fish Warden

COOS BAY-

Closed season on

COQUILLE RIVER-

Closed infalson on

DEALERS -

Classifieation and license fee 27,28

Doaling in salmon without license unlawful-_.

License, how obtained and amount

To report amount of fish purchased

\section{DEPUTY FISE WARDEN -}

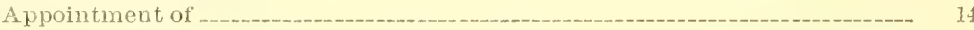

Bond of

Duties of -

Salary of'-_-_-

EXPLOSIVES-

t'se of, prohibited

FIRE. GAME, AND FISH WARDENS-

Ar cletied ex ofncio

\section{FISH WWARDENS-}

Anmual report and suggestions

Appeal from, and costs____- 29,30

Appointment _._. 
Bond.

Certificate sufficient proof of issuance of licenses__________ 31

Compensation and duties____.n_... 14, 45

Concurrent jurisdiction__.... 47

Deputy, duty and compensation_..._.... 14, 45

Fees____ 47, 50

May arrest persons damaging devices marking oyster beds______________ 50

MIay inspect canneries, places of business, and books, for what purpose_-_._-_ 29, 34

Power to search withont warrant_-__-_-_-_-_- 16

Resistance, how punished.-_-_-_- 34

Salary and expenses, how audited and paid_.... 35

To contiscate property, when

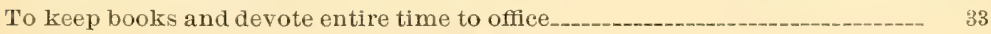

\section{FISH WAY-}

Construction of, at Oregon City.

Hindering passage of fish at Willamette Falls__________- 44

Justices' courts to have concurrent jurisdiction

Obstruction to be removed

Penalty for violation of act.

Removal of obstructions above_-_-_-_-_-_..- 45

Te be under care of Board of Fish Commissioners_____________-_-_-_-_ 44

Unlawful to take fish from or within six hundred feet of any fish way.--_..-_ 19

\section{FISH WHEELS-}

Concealed or covered prohibited .....__... 20, 21

License for stationary _._._._. 23

To be placed in conspicuous place

Unlawful to use, without license-_

What lawful

FISHING DAM -

Unlawful to construct, on certain streams

GILL NETS-

Application for license to be made in writing

License fee for

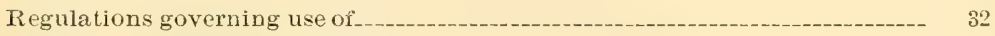

Unlawful to use, without license-_-_-_-_-_- 22

\section{HATCHERIES -}

Commissioners to select and locate-_....... 15

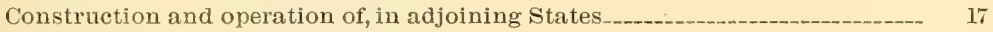

Fund, how constituted and kept______-_ 15

Maintenance of, on Columbia River-_._. 17

Private, payment to out of license money-___-_-_ 16

Rocks and other obstructions for, authorized

Unlawful to injure or destroy racks, traps, etc.-___ 17 
LICENSE-

Procedure to obtain

What to contain.

\section{OBSTRUCTION OF STREAMS-}

Construction of millatam or artificial obstruction prohibited 18,19

\section{OYSTERS-}

Artificial beds private property

Close season as to natural beds.

Natural beds free

Penalty for violation of act

Planted, unlawful to gather or have in possession

Plantations in Netarts Bay-

Regulations for taking, from natural beds

Unlawful to remove devices marking beds

"PERSON" OR "PERSONS"-

Term, what to include.

\section{POUND NET-}

Duty of owner to procure liccuse

Fee for license

Unlawful to use without licenses.

\section{RIPARIAN OWNERS-}

Exclasife pights of

\section{SALMON-}

Burden of proof in proseculing for violations of act

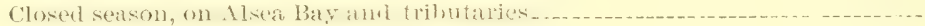

Closed season, on certain Coast streams

Closed season, on Columbia River east of Des Chutes.

Closed season, on Columbia River west of Des Chutes

Closed season, on Coos Bay and tributaries.

Closed season, on Coquille River.

Closed season, on Rogue River and tributaries

Closed season, on Tillamook Bay and tributaries

Closed season, on Umpqua River and tributaries.

Closed scason, on WVillamette Riverand tributaries

Closed season, possession of unlawful

Closed season, contraband, disposition of money______ 12,13

Defined _... 3

Fishing except with hook on Columbia River east of Des Chutes___........- 4

Fishing on Willamette River south of the falls at Oregon City prohibited:--- 4

Fishing without license probibited - 21

Fish whecls or traps in Alsen Bay, river, or tributaries__._-_.-_ 6

Gaffs, spears, and foul hooks prohibited, except by Indians__-__......-_..._ I2

Gravid, unlawful to take-_- 11

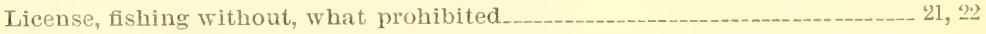

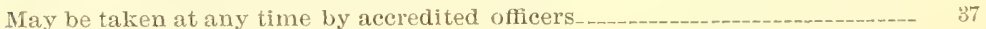

Not to be taken near fishway_____._-_. 18, 19

Penalty for violating act regarding 
Placing explosives or poisonous substances in water unlawful_____________ 13

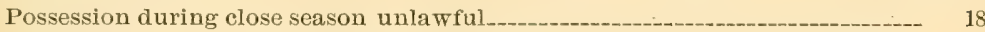

Prohibiting construction, operation, and maintenance of fish traps, nets, ete., in Necanicum River.

Seines and nets, exclusive right of riparian owners_____ 10

Spawning, unlawful to take-_-_-_-_-_- 11

Traps, weirs, fishing dams, and fish wheels in certain streams prohibited_.... 9

Unlawful to take within two miles of any hatchery, rack, or trap_-_-_-_-_-_-_- 17

Wheel, what unlawful _-____- 20

Young, what unlawful to take____- 11

SALT WATER CRAB -

Protection of, in waters of Coos County

Penalty for violation of act

Unlawful to transport, by corporations_. 51

SAWDUST, ETC.-

Discharging of, in any waters flowing into Pacific Ocean prohibited__.......-_ 20

Penalty for violation of act_____

\section{SEINE-}

Mesh to be measured diagonally

Penalty for violation

SET NET -

A pplication for license to use-_-_-_-_-_-_-_-_-_- 23

Construction and operation of, in Neeanicum Creek_______ 10

Fees for license-_-_ 23

Regulations to govern

Unlawful to use, without license

SILVERSTDE SALMON -

Possession of, for sale for transportation during closed season prohibited......

\section{STEELHEAD SALMON -}

Possession of, for sale for transportation during closed season prohibited

Closed for purposes of propagation

STATE BIOLOGIST-

Duty of, to mark location of oysters planted

STURGEON -

Chinese sturgeon lines prohibited

Closed season for._._._. 40,41

Offlcers to seize and destroy lines____ 42

Penalty for violating act_.

Use and disposition of fines

Young, unlawful to take, and penalty 
TRAP, WEIR, ETC-

PAGE

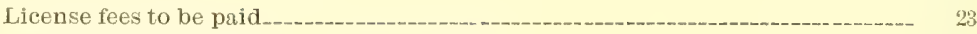

Owner must file map___-_-_- 31

Owner must erect monument____._. 31

To be numbered in conspicnous place-_._._._._._. 31

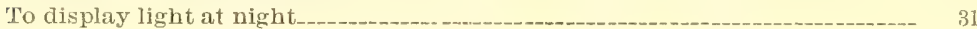

YAQUINA BAY-

Unlawful to fish above mouth of Mill Creek except with hook and line 

. 




